OPEN ACCESS

Edited by:

Hubert Vaudry,

University of Rouen, France

Reviewed by:

James A. Carr,

Texas Tech University, USA

Akiyoshi Takahashi,

Kitasato University, Japan

*Correspondence:

Alex N. Eberle

alex-n.eberle@unibas.ch

tPresent address:

Jean-Philippe Bapst,

Vifor Pharma, Singapore, Singapore

Specialty section:

This article was submitted to Neuroendocrine Science,

a section of the journal

Frontiers in Endocrinology

Received: 01 February 2017

Accepted: 10 April 2017

Published: 26 April 2017

Citation:

Bapst J-P and Eberle AN (2017)

Receptor-Mediated Melanoma

Targeting with Radiolabeled

$\alpha$-Melanocyte-Stimulating

Hormone: Relevance of the Net

Charge of the Ligand.

Front. Endocrinol. 8:93.

doi: 10.3389/fendo.2017.00093

\section{Receptor-Mediated Melanoma Targeting with Radiolabeled $\alpha$-Melanocyte-Stimulating Hormone: Relevance of the Net Charge of the Ligand}

\author{
Jean-Philippe Bapst ${ }^{1 \dagger}$ and Alex N. Eberle ${ }^{1,2 *}$ \\ 'Laboratory of Endocrinology, Department of Biomedicine, University Hospital and University Children's Hospital, \\ University of Basel, Basel, Switzerland, ${ }^{2}$ Collegium Helveticum, ETH Zurich, Zurich, Switzerland
}

A majority of melanotic and amelanotic melanomas overexpress melanocortin type 1 receptors (MC1Rs) for $\alpha$-melanocyte-stimulating hormone. Radiolabeled linear or cyclic analogs of $\alpha-\mathrm{MSH}$ have a great potential as diagnostic or therapeutic tools for the management of malignant melanoma. Compounds such as [ $\left.{ }^{111} \mathrm{In}\right] \mathrm{DOTA}-\mathrm{NAP}$-amide exhibit high affinity for the MC1R in vitro, good tumor uptake in vivo, but they may suffer from relatively high kidney uptake and retention in vivo. We have shown previously that the introduction of negative charges into radiolabeled DOTA-NAP-amide peptide analogs may enhance their excretion and reduce kidney retention. To address the question of where to place negative charges within the ligand, we have extended these studies by designing two novel peptides, Ac-Nle-Asp-His-D-Phe-Arg-Trp-Gly-Lys(DOTA)-D-Asp-DAsp-OH (DOTA-NAP-D-Asp-D-Asp) with three negative charges at the $C$-terminal end (overall net charge of the molecule -2) and DOTA-Gly-Tyr(P)-Nle-Asp-His-D-Phe-ArgTrp- $\mathrm{NH}_{2}$ (DOTA-Phospho- $\mathrm{MSH}_{2-9}$ ) with two negative charges in the $\mathrm{N}$-terminal region (net charge -1). The former peptide showed markedly reduced receptor affinity and biological activity by $>10$-fold compared to DOTA-NAP-amide as reference compound, and the latter peptide displayed similar bioactivity and receptor affinity as the reference compound. The uptake by melanoma tumor tissue of [111In]DOTA-Phospho- $\mathrm{MSH}_{2-9}$ was $7.33 \pm 0.47 \% \mathrm{ID} / \mathrm{g} 4 \mathrm{~h}$ after injection, i.e., almost equally high as with [111/n]DOTANAP-amide. The kidney retention was $2.68 \pm 0.18 \% \mathrm{ID} / \mathrm{g} 4 \mathrm{~h}$ after injection and hence $44 \%$ lower than that of $\left.{ }^{111} \mathrm{In}\right] \mathrm{DOTA}-\mathrm{NAP}$-amide. Over an observation period from 4 to

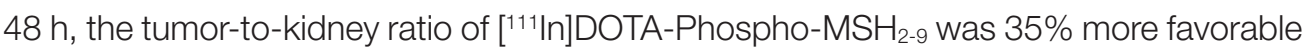

Abbreviations: AUC, area under the curve (quantification during a time interval); Boc, $t$-butoxycarbonyl; $t \mathrm{Bu}$, tert-butyl; DIPEA, $N, N^{\prime}$-diisopropylethylamine; DIPC, $N, N^{\prime}$-diisopropyl-carbodiimde; DOTA, 1,4,7,10-tetraazacyclododecane-1,4,7,10tetra-acetic acid; DTPA, diethylenetriaminepentaacetic acid; Fmoc, fluorenylmethoxycarbonyl; HATU, 0-(7-azabenzotriazole1-yl)-1,1,3,3-tetramethyluronium hexafluorophosphate; HOBt, hydroxybenzotriazole; ID, injected dose; MBM, mouse binding medium; MC1R, melanocortin type 1 receptor; $\alpha$-MSH, $\alpha$-melanocyte-stimulating hormone; MS, mass spectrometry; NOTA, 1,4,7-triazacyclononane-1,4,7-triacetic acid; PAL, 5-(4-aminomethyl-3,5-dimethoxyphenoxy)-valeric acid; Pbf, 2,2,4,6,7-pentamethyldihydrobenzofuran-5-sulfonyl; PBS, phosphate-buffered saline; PEG-PS, poly-ethyleneglycol-polystyrene graft; RP-HPLC, reverse-phase high-pressure liquid chromatography; Suc, succinyl; TBTU, $N, N, N^{\prime}, N^{\prime}$-tetramethyl-O-(benzotriazol1-yl)uronium tetrafluoroborate; TFA, trifluoroacetic acid; Trt, trityl. 
than that of the reference compound. In a comparison of DOTA-NAP-D-Asp-D-Asp, DOTA-Phospho- $\mathrm{MSH}_{2-9}$ and DOTA-NAP-amide with five previously published analogs of DOTA-NAP-amide that altogether cover a range of peptides with an overall net charge between +2 and -2 , we now demonstrate that a net charge of -1 , with the extra negative charges preferably placed in the $N$-terminal region, has led to the lowest kidney uptake and retention. Charges of +2 or -2 markedly increased kidney uptake and retention. In conclusion, the novel DOTA-Phospho- $\mathrm{MSH}_{2-9}$ may represent a new lead compound for negatively charged linear MC1R ligands that can be further developed into a clinically relevant melanoma targeting radiopeptide.

Keywords: melanoma, $\alpha$-melanocyte-stimulating hormone, radiolabeled peptide, phosphopeptide, tumor targeting, net charge, tissue distribution, kidney toxicity

\section{INTRODUCTION}

In the last 30 years, cutaneous malignant melanoma has become one of the most rapidly advancing tumors in the general population and the most commonly occurring tumor among young adults (1); and today, it still continues to increase (2). The prognosis of metastatic melanoma is usually poor. As melanoma cells overexpress membrane-bound melanocortin type 1 receptors (MC1Rs) (3-5), suitable ligands for MC1R are candidates for targeting melanoma with diagnostic or therapeutic radioisotopes (6) or toxin conjugates (7). The natural ligand for MC1R is $\alpha$-melanocyte-stimulating hormone $(\alpha-\mathrm{MSH})$ for which a number of peptide analogs with increased binding affinity have been synthesized in the past, such as linear $\left[\mathrm{Nle}^{4}, \mathrm{D}-\mathrm{Phe}^{7}\right]-\alpha-\mathrm{MSH}$ (NDP-MSH; melanotan I) (8) or cyclic Ac-Nle-cyclo[Asp-His-DPhe-Arg-Trp-Lys]- $\mathrm{NH}_{2}$ (melanotan II) (9) and related peptides (10). For melanoma targeting with radioactive metal isotopes, several linear MSH peptides containing chelators for radiometals were developed (11-15). Of these, ${ }^{111} \mathrm{In}$ - or ${ }^{67 / 68} \mathrm{Ga}$-labeled DOTANAP-amide exhibited the most promising in vivo characteristics as it showed the highest tumor uptake paired with minimal nontumor tissue uptake, except for the kidneys (13).

High uptake and retention of radioactivity by the kidneys and some other organs is a general problem for most peptide radiopharmaceuticals (16). Several strategies have been developed for radiometal-labeled MSH peptides to reduce kidney uptake such as the use of different chelators (e.g., DOTA, NOTA) and radioisotopes and/or variations in the positioning of the chelator within the peptide molecule $(6,17,18)$. Alternatively, introduction of a suitable linker between chelator and peptide may be used (19), or the formation of peptide dimers (20) or cyclic peptides $(21,22)$. Although dimerization produced some very potent high-affinity compounds in vitro, their in vivo characteristics were disappointing (20). By contrast, analysis of a number of cyclized $\alpha$-MSH peptides labeled with ${ }^{111} \mathrm{In},{ }^{177} \mathrm{Lu},{ }^{90} \mathrm{Y},{ }^{99 \mathrm{~m}} \mathrm{Tc}$, or ${ }^{188} \mathrm{Re}$ yielded promising lead candidates (23-28) although these compounds in general suffered equally from high kidney uptake. A direct comparison of a linker-extended ${ }^{64} \mathrm{Cu}$-labeled NOTANAP-amide peptide with a related cyclic peptide showed that both radiopeptides displayed excellent melanoma targeting, however paired with relatively high kidney uptake (29); the overall radiopharmacological characteristics of the linear peptide were superior in this study.

Another approach to reduce uptake of radioactivity by the kidneys is coinjection of radiopeptides with basic amino acids. As the surface of proximal tubular cells in the kidneys is negatively charged and electrostatic interactions contribute greatly to the uptake of positively charged peptide molecules, basic amino acids may compete with the uptake of radiopeptides and hence reduce it (30). This method was first applied for ${ }^{111}$ In-labeled DTPAoctreotide $(31,32)$ and ${ }^{90}$ Y-labeled DOTA-[Tyr $\left.{ }^{3}\right]$-octreotide $(32,33)$. In particular, coinjection of D-Lys markedly reduced kidney uptake by up to $65 \%$ without affecting tumor uptake (32). A lesser reduction was achieved by coinfusion of Lys and Arg with ${ }^{188}$ Re-labeled cyclized MSH (34) or with ${ }^{111}$ In-labeled DOTA-NAP-amide (Froidevaux and Eberle, unpublished). Although successful for some of the radiopeptides, coinjection of basic amino acids only partially solved the problem of kidney toxicity by the accumulated radioactivity.

Following basic reabsorption studies in the kidneys with positively, neutrally, and negatively charged proteins $(35,36)$, Kok et al. (37) demonstrated that the excretion of succinylated lysozyme is dramatically increased compared to the nonsuccinylated molecule with six amino groups, suggesting that reduction of the positive net charge of lysozyme had a beneficial effect on urinary excretion. Akizawa et al. (38) confirmed the influence of negative charges on the excretion of ${ }^{111}$ In-labeled DTPA-octreotide peptides containing modifications in position 1 (Asp vs. Phe or Met vs. Lys): the lowest radioactivity counts in the kidneys were found with [ $\left.{ }^{111} \mathrm{In}\right] \mathrm{DTPA}-\left[\mathrm{Asp}^{1}\right]$-octreotide, whereas the highest were seen with $\left[{ }^{111} \mathrm{In}\right] \mathrm{DTPA}-\left[\mathrm{Lys}^{1}\right]$-octreotide. Less conspicuous data were obtained with $\left[{ }^{111} \mathrm{In}\right]$ DOTA-NAPamide containing different charges in the $C$-terminal region: although with the DOTA-NAP-amide analog [DOTA-Nle ${ }^{4}, \mathrm{Asp}^{5}$, $\left.\mathrm{D}-\mathrm{Phe}^{7}, \mathrm{Lys}^{11}(\mathrm{Suc})\right]-\alpha-\mathrm{MSH}_{4-11}$-carboxylate, a negative charge in the $C$-terminus reduced kidney uptake of the radiopeptide, tumor uptake was also affected, and hence, the tumor-to-kidney ratio was even lower than that of the parent molecule with noncharged $C$-terminal amide (14). By contrast, introduction of a Glu residue at the $N$-terminus of a Re-cyclized DOTA-containing $\mathrm{MSH}$ peptide increased the tumor-to-kidney ratio, demonstrating the beneficial effect of an additional negative charge (26). 
To compare the pharmacokinetic properties of linear ${ }^{111}$ In-labeled DOTA-MSH peptide analogs containing a net charge ranging from +2 to -2 , we synthesized and biologically characterized two new peptides, Ac-Nle-Asp-His-D-Phe-ArgTrp-Gly-Lys(DOTA)-D-Asp-D-Asp-OH (abbreviated name: DOTA-NAP-D-Asp-D-Asp) and DOTA-Gly-Tyr(P)-Nle-AspHis-D-Phe-Arg-Trp- $\mathrm{NH}_{2}$ (DOTA-Phospho- $\mathrm{MSH}_{2-9}$ ), and we also included DOTA-NAP-amide as a reference compound in this study (Figure 1). Biodistribution data obtained in tumor-bearing mice were compared with the data of the previously published linear MSH analogs (14). The analysis showed that DOTA-Phospho$\mathrm{MSH}_{2-9}$ yielded the best tumor-to-kidney ratio of all linear MSH peptides so far investigated, demonstrating that an overall net charge of the peptide of -1 with a negatively charged $N$-terminal region resulted in the most favorable biodistribution properties.

\section{MATERIALS AND METHODS}

\section{Reagents}

$\alpha$-Melanocyte-stimulating hormone was a gift from the Novartis Institutes of Biomedical Research (Basel, Switzerland). $\left[\mathrm{Nle}^{4}, \mathrm{D}-\mathrm{Phe}^{7}\right]-\alpha-\mathrm{MSH} \quad$ (NDP-MSH) was obtained from Bachem (Bubendorf, Switzerland). DOTA-tris(tert-butyl ester) (1,4,7,10-tetraazacyclododecane-1,4,7-tris-tert-butyl acetate10-acetic acid) was purchased from Macrocyclics (Dallas, TX, USA), Fmoc-PAL-PEG-PS resin from Applied Biosystems (Rotkreuz, Switzerland), Fmoc-D-Asp $(t \mathrm{Bu})$-TentaGel S AC resin from Rapp-Polymere (Tübingen, Germany), Fmoc-amino acids from Novabiochem (Läufelfingen, Switzerland), and Kaiser test kits from Sigma-Aldrich (Buchs, Switzerland). N-Succinimidyl iodoacetate and iodogen tubes were from Pierce Biotechnology (Rockford, IL, USA), Na ${ }^{125} \mathrm{I}(3.7 \mathrm{GBq} / \mathrm{mL}$ ) from Perkin Elmer (Waltham, MA, USA), and ${ }^{111} \mathrm{InCl}_{3}(370 \mathrm{MBq} / \mathrm{mL})$ from Mallinckrodt (Petten, The Netherlands). 1,10-Phenanthroline was bought from Merck (Darmstadt, Germany), and all other organic reagents were obtained from Sigma-Aldrich. All reagents were of highest purity available. Cell culture media were from Biochrom AG (Berlin, Germany) and Sigma-Aldrich. Penicillin, streptomycin, vitamins, and non-essential amino acids were bought from Gibco/Invitrogen (Carlsbad, CA, USA) or Sigma-Aldrich.

\section{Instrumentation}

Continuous-flow peptide synthesis was carried out on a Pioneer peptide synthesizer from PerSeptive Biosystems (Framingham, MA, USA). Analytical reverse-phase high-pressure liquid chromatography (RP-HPLC) was performed on a PU-980 system from Jasco (Easton, MD, USA) using a Vydac 218TP54 C18 (5 $\mu \mathrm{m}$, $4.6 \mathrm{~mm} \times 250 \mathrm{~mm})$ or a Phenomenex Jupiter C18 $300 \AA$ (5 $\mu \mathrm{m}$, $4.6 \mathrm{~mm} \times 250 \mathrm{~mm}$ ) analytical column. DOTA-NAP-amide$\mathrm{D}$-Asp-D-Asp was chromatographed with a gradient between solvent $\mathrm{A}\left[0.1 \%\right.$ trifluoroacetic acid (TFA) in $\left.\mathrm{H}_{2} \mathrm{O}\right]$ and solvent $\mathrm{B}$ $\left(0.1 \%\right.$ TFA in $70: 30$ acetonitrile/ $\left.\mathrm{H}_{2} \mathrm{O}\right)$. The 40 -min gradient cycle consisted of the following parts: $95 \%$ A (0-2 min), 95-70\% A (2-10 $\mathrm{min}), 70-30 \% \mathrm{~A}$ (10-30 $\mathrm{min}), 30-5 \% \mathrm{~A}$ (30-34 $\mathrm{min}), 5 \%$ A (34-36 min), 5-95\% A (36-38 min), and 95\% A (38-40 min); the flow rate was $1 \mathrm{~mL} / \mathrm{min}$. UV absorption was recorded at $280 \mathrm{~nm}$ using a Jasco UV-1570 detector. DOTA-Phospho- $\mathrm{MSH}_{2-9}$ was chromatographed on a Phenomenex Jupiter column using the same gradient, except that solvent A was replaced by $0.02 \mathrm{M}$ ammonium acetate. Mass spectra were determined on a Finnigan LCQ Deca electrospray ion trap mass spectrometry (MS) system.

The purity of the radioligands was assessed by RP-HPLC using a dedicated Jasco PU-980 chromatography system equipped with a Spherisorb ODS2/5- $\mu \mathrm{m}$ column and a Radiomatic 500TR LB506C1 $\gamma$-detector (Packard, Meriden, CT, USA). Solvent A was $0.1 \%$ TFA in $\mathrm{H}_{2} \mathrm{O}$; solvent $\mathrm{B}$ was $0.1 \%$ TFA in acetonitrile; the gradient consisted of $96 \%$ A (0-2 min), 96-45\% A (2-22 min), 45-25\% A (22-30 min), 25\% A (30-32 min), and 25-96\% A (32-34 min);

$$
\begin{aligned}
& \boldsymbol{\alpha} \text {-MSH } \\
& \stackrel{1}{1} \begin{array}{c}
13 \\
\text { Ac }- \text { Ser }- \text { Tyr }- \text { Ser }- \text { Met }- \text { Glu }- \text { His }- \text { Phe }- \text { Arg }- \text { Trp - Gly - Lys - Pro - Val }-\mathrm{NH}_{2}
\end{array}
\end{aligned}
$$

DOTA-NAP-amide

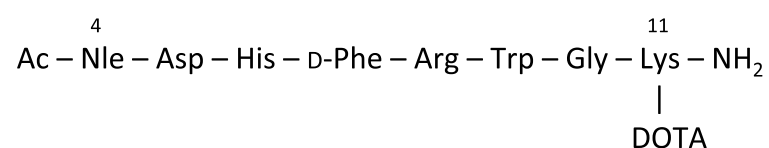

DOTA-NAP-D-Asp-D-Asp

$$
\text { Ac }-\stackrel{4}{ } \mathrm{Nle}-\mathrm{Asp}-\mathrm{His}-\mathrm{D}-\mathrm{Phe}-\mathrm{Arg}-\mathrm{Trp}-\mathrm{Gly}-\underset{\text { DOTA }}{11} \text { Lys - D-Asp - D-Asp }-\mathrm{NH}_{2}
$$

DOTA-Phospho-MSH ${ }_{2-9}$

$$
\text { DOTA }-\stackrel{2}{\text { Gly }_{\mathrm{OPO}}} \underset{3}{\mathrm{Ty}}-\mathrm{Nle}-\mathrm{Asp}-\mathrm{His}-\mathrm{D}-\mathrm{Phe}-\mathrm{Arg}-\mathrm{Trp}-\mathrm{NH}_{2}
$$

FIGURE 1 | Amino acid sequence of $\alpha$-MSH, DOTA-NAP-amide, DOTA-NAP-D-Asp-D-Asp, and DOTA-Phospho-MSH ${ }_{2-9}$. 
the flow rate was $1.0 \mathrm{~mL} / \mathrm{min}$. A cell harvester (Packard) was used to collect cell-bound radioactivity from binding assays on filters. Their radioactivity was measured on a TopCount microplate scintillation counter (Packard). Radioactivity in internalization and biodistribution assays was measured on a Cobra II AutoGamma $\gamma$-counter (Packard). For bioassays, melanin content in cell culture media of each well was quantified on a Spectra Max 190 microplate reader (Molecular Devices, Menlo Park, CA, USA) using a wavelength of $310 \mathrm{~nm}$.

\section{Peptide Synthesis General}

Continuous-flow solid-phase peptide synthesis was used, combined with Fmoc strategy and the following resins: Flow-compatible Fmoc-PAL-PEG-PS polystyrene resin containing the acid-labile amide linker 5-(4-aminomethyl3,5-dimethoxyphenoxy)-valeric acid (substitution $0.21 \mathrm{mmol} / \mathrm{g}$ ) for NAP-amide and DOTA-Phospho- $\mathrm{MSH}_{2-9}$, and Fmoc-D$\operatorname{Asp}(t \mathrm{Bu})$-TentaGel S AC resin, a low crosslinked polystyrene matrix resin, for NAP-amide-D-Asp-D-Asp-OH. Amino acid side chains were protected as follows: Trt for Cys and His, $t$-butoxycarbonyl (Boc) for Lys and Trp, tert-butyl $(t \mathrm{Bu})$ for Asp and $\mathrm{D}-\mathrm{Asp}$, and $\mathrm{Pbf}$ for Arg. Manual Fmoc deprotection was done in $20 \%$ piperidine/DMF for $20 \mathrm{~min}$, followed by a short wash with $20 \%$ piperidine/DMF and five washes with DMF; completion of deprotection was assessed by Kaiser test. Cleavage of the peptide from the resin was performed with a solution of 90\% TFA, 5\% thioanisole, $4.5 \% \mathrm{H}_{2} \mathrm{O}$, and $0.5 \%$ 1,2-ethanedithiol. After $2 \mathrm{~h}$, the solution was filtrated, and the peptide precipitated with a 10 -fold volume of $t \mathrm{Bu}$-methyl ether or diethylether. All reactions and manipulations with DOTA were carried out in acid-treated (1 M $\mathrm{HCl},>1 \mathrm{~h}$ ) glassware.

\section{DOTA-NAP-Amide}

NAP-amide (13) was assembled as described above. The free $N$-terminus was acetylated at room temperature for 24 h by incubation of the peptide-resin with 2 equivalents of $p$-nitrophenyl acetate, preactivated with hydroxybenzotriazole (HOBt) (1 eq) in DMF for $10 \mathrm{~min}$. The resin was filtrated and washed $5 \times$ with DMF and $4 \times$ with isopropanol and then submitted to cleavage as described above. The DOTA moiety was coupled to the $\varepsilon$-amino group of the $C$-terminal Lys residue, the peptide conjugate deprotected (90\% TFA, $4 \mathrm{~h}$ ) and purified by RP-HPLC $\left(t_{\mathrm{R}}=9.53 \mathrm{~min}\right)$. Calculated monoisotopic mass: $1,485.64 / \mathrm{gmol}$; found: $1,485.65 / \mathrm{gmol}$.

\section{DOTA-NAP-D-Asp-D-Asp}

NAP-amide-D-Asp-D-Asp-OH was synthesized, acetylated, and cleaved from the resin as described for NAP-amide (Figure 2A). NAP-amide-D-Asp-D-Asp-OH was purified by $\operatorname{HPLC}\left(t_{\mathrm{R}}=16.1 \mathrm{~min}\right)$ and lyophilized. Calculated monoisotopic mass: 1,330.40/gmol; found: 1,329.9/gmol. The deprotected peptide (1 eq) was conjugated with DOTA-tris(t-butyl ester) ( 1 eq) and preincubated with HATU (1.2 eq) for $10 \mathrm{~min}$, in the presence of DIPEA (2 eq) using DMF as a solvent. After $1 \mathrm{~h}$ at room temperature, half of the initial quantity of preactivated DOTA-tris( $t$-butyl ester) was added to the mixture, and after a total reaction time of $2 \mathrm{~h}$, the peptide was precipitated in ice-cold diethylether. The DOTA moiety was then deprotected by addition of $90 \%$ TFA ( $4 \mathrm{~mL}$ per $5 \mathrm{mg}$ of peptide). The mixture was stirred for $4 \mathrm{~h}$, and deprotected DOTA-peptide was precipitated in icecold diethylether, resuspended in 10\% acetic acid, and purified by RP-HPLC ( $\left.t_{\mathrm{R}}=16.7 \mathrm{~min}\right)$. Calculated monoisotopic mass: $1,716.80 / \mathrm{gmol}$; found: $1,716.79 / \mathrm{gmol}$.

\section{DOTA-Phospho-MSH ${ }_{2-9}$}

The first amino acid was coupled to the Fmoc-PAL-PEG-PS resin manually; Fmoc-Trp(Boc)-OH (3 eq) was preactivated with HOBt $(3 \mathrm{eq}+15 \%)$ for $10 \mathrm{~min}$ (Figure 2B). This mixture was added to a suspension of the Fmoc-deprotected resin, followed by DIPC ( 3 eq) for overnight reaction. The resin was washed $5 \times$ with DMF, and completion was checked by Kaiser test. The subsequent synthesis steps up to $\mathrm{Nle}^{3}$ were done on the peptide synthesizer. After deprotection of the $\mathrm{N}$-terminal Fmoc-protecting group, Fmoc-Tyr(PO(OBzl)-OH)-OH (5 eq) was preactivitated with HOBt (1 eq) and then manually coupled to the peptide (1 eq peptide on resin) by addition of TBTU (1 eq) and DIPEA (15 eq). After overnight incubation, the reaction was repeated under the same conditions, and then the Fmoc-protecting group was cleaved. The final amino acid Fmoc-Gly-OH was coupled in the same way. After Fmoc deprotection, DOTA was coupled to the peptide still on the resin by preactivating DOTA (3 eq) with HATU ( 3 eq) for $10 \mathrm{~min}$ and then by adding DIPEA ( 9 eq) to the resin suspension (1 eq peptide) for overnight reaction. The peptide was simultaneously cleaved from the resin and deprotected by addition of $90 \%$ TFA for $4 \mathrm{~h}$ and precipitated with ice-cold diethylether. DOTA-Phospho- $\mathrm{MSH}_{2-9}$ was finally purified by RP-HPLC $\left(t_{\mathrm{R}}=16.5 \mathrm{~min}\right)$. Calculated monoisotopic mass: 1,558.59/gmol; found: $1,558.30 / \mathrm{gmol}$.

\section{Radiolabeling of Peptides Labeling with ${ }^{111}$ In}

Incorporation of ${ }^{111}$ In into DOTA-peptides was performed by the addition of $55.5 \mathrm{MBq}$ of ${ }^{111} \mathrm{InCl}_{3}$ to the DOTA-peptides $(10 \mathrm{nmol})$ that had been dissolved in $54 \mu \mathrm{L}$ acetate buffer $(0.4 \mathrm{M}, \mathrm{pH} 5)$ containing $2 \mathrm{mg}$ of gentisic acid. Incubation for $10 \mathrm{~min}$ at $95^{\circ} \mathrm{C}$ allowed completion of the reaction. The radiolabeled DOTApeptides were purified on a small RP cartridge (Sep-Pak C18, Waters) by first washing the column with $0.4 \mathrm{M}$ sodium acetate buffer ( $\mathrm{pH} 7$ ) and then eluting the peptides with ethanol. The purity of the radioligands was assessed by RP-HPLC/ $\gamma$ detection as described above. The specific activity of the radioligand was always $>7.4 \mathrm{GBq} / \mu \mathrm{mol}$.

\section{Radioiodination}

NDP-MSH (12.14 nmol) was mixed with $\mathrm{Na}^{125}$ I (37 MBq; Perkin Elmer) in $60 \mu \mathrm{L}$ phosphate buffer $(0.3 \mathrm{M}, \mathrm{pH} 7.4)$ in a Iodogen ${ }^{\circledR}$ precoated tube. After a 15 -min incubation at room temperature under agitation, the iodination mixture was loaded onto a SepPak C18 cartridge, which was washed consecutively with water and acetic acid $(0.5 \mathrm{M})$. Finally, the peptide was eluted with methanol. The collected fractions containing [ $\left.{ }^{125} \mathrm{I}\right] \mathrm{NDP}-\mathrm{MSH}$ were supplemented with dithiothreitol $(1.5 \mathrm{mg} / \mathrm{mL})$ and stored at $-20^{\circ} \mathrm{C}$. Each binding experiment was preceded by an additional 


\section{A Ac-Nle-Asp-His-D-Phe-Arg-Trp-Gly-Lys(DOTA)-D-Asp-D-Asp-OH \\ [DOTA-NAP-D-Asp-D-Asp]}<smiles>CCCCC(NC(=O)C(CC(=O)O)NC(=O)C(Cc1c[nH]cn1)NC(=O)C(Cc1ccccc1)NC(=O)C(CCCNC(=N)N)NC(=O)C(Cc1c[nH]c2ccccc12)NC(=O)CNC(=O)C(CCCCNC(=O)CN(CCN(CCN(CC(=O)O)CC(=O)O)CC(=O)O)CCN(CC(=O)O)CC(=O)O)NC(=O)C(CC(=O)O)NC(=O)C(CC(=O)O)C(=O)O)C(=O)O</smiles>

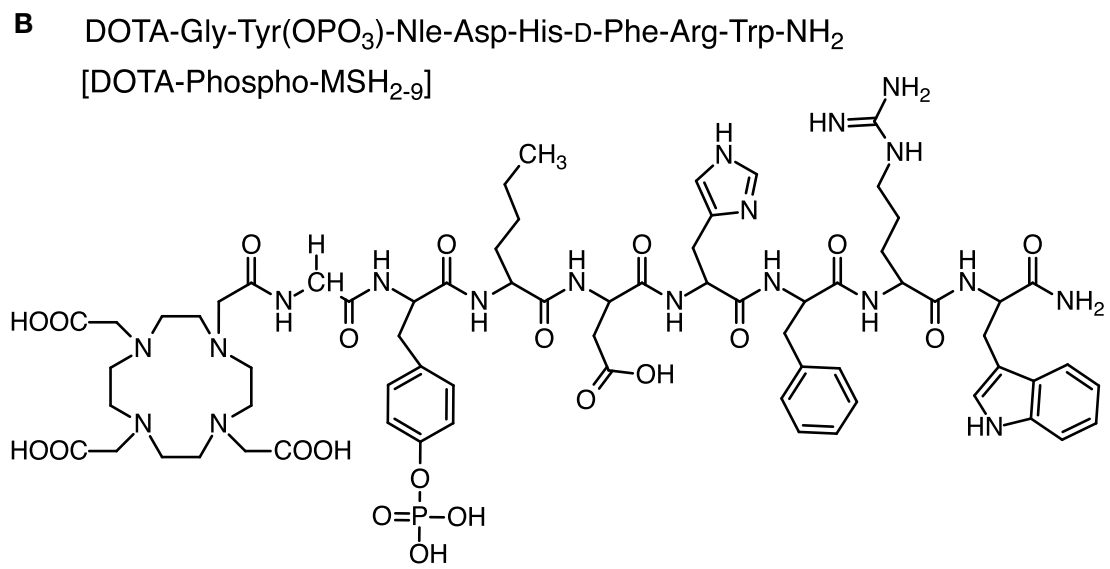

FIGURE 2 | Chemical structure of DOTA-NAP-D-Asp-D-Asp (A) and DOTA-Phospho-MSH ${ }_{2-9}$ (B)

purification of the radiotracer by RP-HPLC and subsequent lyophilization from lactose/bovine serum albumin (BSA) (20 mg of each per milliliter of tracer solution).

\section{Cell Culture}

Mouse B16-F1 melanoma cells (39) were cultured in modified Eagle's medium (MEM) containing 10\% heat-inactivated fetal calf serum, $2 \mathrm{mmol} / \mathrm{L}$ L-glutamine, $1 \%$ non-essential amino acids, $1 \%$ vitamin solution, $50 \mathrm{IU} / \mathrm{mL}$ penicillin, and $50 \mu \mathrm{g} / \mathrm{mL}$ streptomycin, in a humidified atmosphere consisting of $95 \%$ air and $5 \% \mathrm{CO}_{2}$ at $37^{\circ} \mathrm{C}$. For cell expansion or experiments with isolated cells, the B16-F1 cells were detached with $0.02 \%$ EDTA in phosphate-buffered saline (PBS) $(150 \mathrm{mM}, \mathrm{pH} 7.2-7.4)$. The human HBL melanoma cell line $(3,4)$ was cultured in modified RPMI medium supplemented with $10 \%$ heat-inactivated fetal calf serum, $2 \mathrm{mM}$ L-glutamine, $50 \mathrm{IU} / \mathrm{mL}$ penicillin, and $50 \mu \mathrm{g} / \mathrm{mL}$ streptomycin in the same conditions as for B16-F1 cells.

\section{In Vitro Binding Assay}

Triplicates of $100-\mu \mathrm{L}$ volumes of B16-F1 or HBL cell suspensions adjusted to $4 \times 10^{6} / \mathrm{mL}$ were incubated in 96-well U-bottom microplates (Falcon 3077). The binding medium consisted of MEM with Earle's salts, $0.2 \%$ BSA, and $0.3 \mathrm{mM} \mathrm{1,10-phenanth-}$ roline. This binding medium was called mouse binding medium (MBM). Triplicates of competitor peptide solution $(50 \mu \mathrm{L})$ yielding final concentrations ranging from $1 \times 10^{-6}$ to $1 \times 10^{-12}$ $\mathrm{M}$ were added. [ $\left.{ }^{125} \mathrm{I}\right] \mathrm{NDP}-\mathrm{MSH}(50,000 \mathrm{cpm})$ in $50 \mu \mathrm{L}$ was finally added to each well. The plates were incubated at $15^{\circ} \mathrm{C}$ for $3 \mathrm{~h}$ for B16-F1 cells and at $37^{\circ} \mathrm{C}$ for $2 \mathrm{~h}$ for HBL cells. The incubation was stopped by covering the plates with ice for $10 \mathrm{~min}$. A cell harvester was used to collect cell-bound radioactivity on filters (Packard Unifilter-96 GF/B). The collected radioactivity was counted on a TopCount scintillation counter (Packard) after addition of $50 \mu \mathrm{L}$ Microscint-20 scintillation cocktail (Perkin Elmer). The $\mathrm{IC}_{50}$ values were calculated with the Prism 6 software (GraphPad Software Inc., San Diego CA, USA).

\section{In Vitro Melanin Assay}

The biological activity of the $\alpha$-MSH derivatives was assessed with an in situ melanin assay (40). Briefly, B16-F1 cells $(2,500$ cells per well in $100 \mu \mathrm{L}$ ) were distributed into 96-well flat-bottom cell culture plates. MEM without phenol red, supplemented 
with $10 \%$ heat-inactivated fetal calf serum, $2 \mathrm{mM}$ L-glutamine, $0.31 \mathrm{mmol} / \mathrm{L} \mathrm{L}$-tyrosine, $1 \%$ non-essential amino acids, $1 \%$ vitamin solution, $50 \mathrm{IU} / \mathrm{mL}$ penicillin, and $50 \mu \mathrm{g} / \mathrm{mL}$ streptomycin, was used as culture medium. After overnight incubation at cell culture conditions mentioned above, concentrations of $\alpha$-MSH derivatives ranging from $1 \times 10^{-8}$ to $1 \times 10^{-12}$ in $100-\mu \mathrm{L}$ volumes were added (in threefold dilution steps), and the incubation was continued for an additional $72 \mathrm{~h}$. Melanin production was quantified by determining the absorbance at $310 \mathrm{~nm}$ in a microplate reader.

\section{In Vitro Internalization Assay}

B16-F1 cells were seeded in six-well plates and incubated overnight in $\mathrm{MEM}$ at $37^{\circ} \mathrm{C}$. For the internalization experiments, MEM was replaced by $1 \mathrm{~mL}$ MBM (see above) as internalization buffer. After a 1-h incubation at $37^{\circ} \mathrm{C}, 74 \mathrm{kBq}$ of radioligand ( ${ }^{111} \mathrm{In}$-labeled peptides) was added, and the plates were incubated for different time periods. Non-specific internalization was determined by addition of $50 \mu \mathrm{L}$ of a $1 \mu \mathrm{M} \alpha-\mathrm{MSH}$ solution to the incubation mixture. After the desired incubation times, the cells were extensively washed with $\mathrm{MBM}$ kept at $37^{\circ} \mathrm{C}$ to remove excess radioligand. Incubation in $2 \mathrm{~mL}$ ice-cold acid buffer (acetate-buffered Hank's balanced salt solution, $\mathrm{pH}$ 5) for $10 \mathrm{~min}$ allowed dissociation of surface-bound ligand. After collection of the acid buffer fraction, the cells were rinsed once with cold MBM, and the washings were pooled with the acid buffer fraction. The cells were washed again with $\mathrm{MBM}$ kept at $37^{\circ} \mathrm{C}$, lysed in a $1 \%$ Triton X-100 solution, and finally transferred to tubes for quantification. The radioactivity of all collected fractions was measured in a $\gamma$-counter. A counting plate underwent the same treatment as the plate incubated for the longest time, but its cells were detached with $0.02 \%$ EDTA in PBS instead of being lysed with the Triton X-100 solution. Cells from three wells were collected, counted, and thus allowed for normalization of the results obtained. Results were expressed as percent of the added dose per million cells.

\section{In Vivo Biodistribution and Stability of the Radioligands in B16-F1 Tumor-Bearing Mice}

About $5 \times 10^{5}$ B16-F1 cells were implanted subcutaneously to female $\mathrm{B} 6 \mathrm{D} 2 \mathrm{~F} 1$ mice $(\mathrm{C} 57 \mathrm{BL} / 6 \times \mathrm{DBA} / 2 \mathrm{~F} 1$ hybrids; breeding pairs obtained from IFFA-CREDO, France). Seven days later, $185 \mathrm{kBq}$ of ${ }^{111}$ In-labeled ligand in $200 \mu \mathrm{L}$ PBS/0.1\% BSA were injected intravenously into the lateral tail vein of each mouse. Control mice were injected with a mixture of the tracer and $50 \mu \mathrm{g}$ $\alpha-\mathrm{MSH}$ to determine the non-specific uptake of radioligand. The animals were sacrificed 4,24 , and 48 h postinjection, dissected, and the tissues of interest collected, rinsed of excess blood, and weighed. The radioactivity emitted by each organ was measured in a $\gamma$-counter to determine the tissue uptake as percentage of the injected dose (ID) per gram of tissue. The total of injected radioactivity per animal was determined by extrapolation from the counts of a standard collected from the injection solution for each animal. Urine samples were collected at 10, 15, and $20 \mathrm{~min}$ and $4 \mathrm{~h}$ after injection and kept frozen at $-80^{\circ} \mathrm{C}$ until use. Urine $(1 \mathrm{vol})$ was mixed with methanol $(2 \mathrm{vol})$ to precipitate proteins, and the supernatant was analyzed by RP-HPLC/ $\gamma$-detection, as described in Ref. (12).

\section{Analysis of Data}

Results are expressed as means \pm SEM, unless otherwise stated. The statistical evaluation of data was performed using the oneor two-way ANOVA test. When significant overall effects were obtained by ANOVA, multiple comparisons were made with the Bonferroni correction. $P<0.05$ was considered statistically significant. The area under the curve (AUC) was calculated with the GraphPad Prism 6 software for the indicated period of time, using the mean tissue uptake value at each time point.

\section{RESULTS}

\section{Peptide Synthesis}

All DOTA-peptides were obtained in $>99 \%$ purity. The synthesis of DOTA-NAP-amide had an overall yield (after RP-HPLC purification) of $15 \%$, DOTA-NAP-D-Asp-D-Asp $8.3 \%$, and DOTA-Phospho- $\mathrm{MSH}_{2-9}$ 5.3\%. The expected molecular weights were confirmed by MS. The net charges of DOTA-NAP-D-Asp-DAsp and DOTA-Phospho- $\mathrm{MSH}_{2-9}$ at physiological $\mathrm{pH}$ are -2 and -1 , respectively, calculated on the basis of known $\mathrm{pK}_{\mathrm{a}}$ values for amino acid residues and functional groups.

\section{In Vitro Receptor-Binding Affinity and Biologic Activity}

The binding affinity of the peptides to MC1R was assessed by competition binding assays using [ $\left.{ }^{125} \mathrm{I}\right]-\mathrm{NDP}-\mathrm{MSH}$ as radioligand and both murine B16-F1 and human HBL cells. Table 1 summarizes the $\mathrm{IC}_{50}$ values obtained for the tested peptide compared to the values of the native ligand $\alpha-\mathrm{MSH}$ and the reference peptide DOTA-NAP-amide. DOTA-Phospho- $\mathrm{MSH}_{2-9}$ displayed affinities in the nanomolar range on both cell lines. Although the $\mathrm{IC}_{50}$ obtained for DOTA-Phospho- $\mathrm{MSH}_{2-9}$ with B16-F1 cell line was slightly lower than that of DOTA-NAP-amide $(2.32 \pm 0.80$ vs. $1.38 \pm 0.35 \mathrm{nmol} / \mathrm{L})$, the binding affinity with $\mathrm{HBL}$ cells was

TABLE 1 | Receptor-binding potency and biological activity of DOTA-MSH analogs using mouse B16-F1 and human HBL melanoma cells.

\begin{tabular}{|c|c|c|c|}
\hline \multirow[t]{2}{*}{ Peptide } & \multicolumn{2}{|c|}{$\begin{array}{l}\text { Receptor-binding potency } \\
\qquad \mathrm{IC}_{50}(\mathrm{nmol} / \mathrm{L})^{\mathrm{a}}\end{array}$} & \multirow{2}{*}{$\begin{array}{c}\begin{array}{c}\text { Biological activity } \\
r E C_{50}[\alpha-m e l a n o c y t e- \\
\text { stimulating hormone } \\
(\alpha-\mathrm{MSH})=1]^{\mathrm{b}}\end{array} \\
\mathrm{B} 16-\mathrm{F} 1\end{array}$} \\
\hline & B16-F1 & HBL & \\
\hline$\alpha-\mathrm{MSH}$ & $1.50 \pm 0.14$ & $1.91 \pm 0.26$ & 1 \\
\hline DOTA-NAP-amide & $1.38 \pm 0.35$ & $3.09 \pm 1.11$ & $0.66 \pm 0.35$ \\
\hline $\begin{array}{l}\text { DOTA-NAP-D-Asp- } \\
\text { D-Asp }\end{array}$ & $19.67 \pm 4.48^{c}$ & $29.80 \pm 7.96^{c}$ & $7.66 \pm 0.33^{c}$ \\
\hline $\begin{array}{l}\text { DOTA-Phospho- } \\
\mathrm{MSH}_{2-9}\end{array}$ & $2.32 \pm 0.80$ & $3.03 \pm 0.59$ & $0.85 \pm 0.11$ \\
\hline
\end{tabular}

${ }^{a} / C_{50}$ values are the concentrations inducing half-maximal binding inhibition of the $M S H$ analogs and were determined in competition binding experiments using [125I]-NDP-MSH as radioligand and mouse B16-F1 and human HBL human melanoma cells ( $n=3-20$ ). ${ }^{b} \mathrm{rEC} \mathrm{C}_{50}$ values represent the relative concentrations compared to $\alpha-M S H(=1)$ inducing half-maximal melanin production by B16-F1 cells $(n=3-13)$.

${ }^{c} P<0.05$ vs. DOTA-NAP-amide. 
comparable $(3.03 \pm 0.59$ vs. $3.09 \pm 1.11 \mathrm{nmol} / \mathrm{L})$. DOTA-Phospho$\mathrm{MSH}_{2-9}$ displayed good $\alpha-\mathrm{MSH}$ agonist activity (Table 1), as demonstrated by the induction of melanin synthesis by B16-F1 cells at a dose matching its $\mathrm{IC}_{50}$. By contrast, $C$-terminal extension of DOTA-NAP by D-Asp-D-Asp led to a $~ 10$-fold lower MC1R affinity compared to that of DOTA-NAP-amide with both B16-F1 and HBL cells. The biological activity in the melanin assay was also around 11-fold lower than the reference peptide.

\section{Internalization}

$\left[{ }^{111} \mathrm{In}\right]$ DOTA-NAP-D-Asp-D-Asp and [ $\left.{ }^{111} \mathrm{In}\right]$ DOTA-Phospho$\mathrm{MSH}_{2-9}$ exhibited excellent internalization profiles when studied in vitro with cultured B16-F1 cells (Figure 3). The plateau phase was not quite reached by the first peptide after $3.5 \mathrm{~h}$, probably because of the lower receptor affinity; this may predict lower in vivo tumor uptake. By contrast, the plateau phase for [ $\left.{ }^{111} \mathrm{In}\right]$ DOTA-Phospho- $\mathrm{MSH}_{2-9}$ was almost complete after $3.5 \mathrm{~h}$, indicating that maximal internalization of the peptide was reached after $4 \mathrm{~h}$, the first test point with in vivo biodistribution studies. It appears that MC1R internalization was not altered by the negatively charged ligands.

\section{Biodistribution in Tumor-Bearing Mice}

Tissue distributions in B16-F1 melanoma-bearing mice of [ $\left.{ }^{111} \mathrm{In}\right]$ DOTA-NAP-D-Asp-D-Asp and [ $\left.{ }^{111} \mathrm{In}\right]$ DOTA-Phospho- $\mathrm{MSH}_{2-9}$
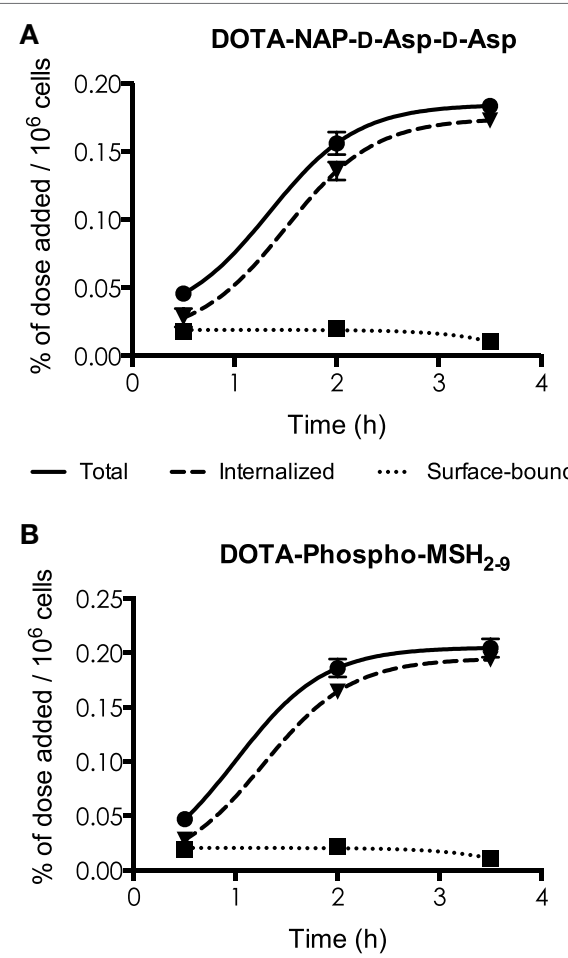

FIGURE 3 | Determination of internalization of [ $\left.{ }^{111} \mathrm{In}\right]$ DOTA-NAP-DAsp-D-Asp (A) and [ $\left.{ }^{111} \mathrm{In}\right] \mathrm{DOTA}-\mathrm{Phospho-} \mathrm{MSH}_{2-9}(\mathrm{~B})$ by cultured B16-F1 cells exposed to the peptides at $37^{\circ} \mathrm{C}$ for $0.5,2$, and $3.5 \mathrm{~h}$. Surfacebound radioligand was released by an acid buffer wash, and internalized radioligand was determined by lysing cells with detergent. Results are expressed in percent of the added dose per million cells. were compared with the reference peptide [ ${ }^{111}$ In]DOTA-NAPamide (Table 2). Tissues, including melanoma tumors, were collected 4, 24, and 48 after injection of the radiopeptides. Clearance from the blood was faster for the two new radiopeptides compared with the reference peptide as almost no radioactivity could be detected after $4 \mathrm{~h}$. Kidney uptake of [ $\left.{ }^{111} \mathrm{In}\right]$ DOTA-NAPD-Asp-D-Asp was $5.95 \pm 0.85 \% \mathrm{ID} / \mathrm{g} 4 \mathrm{~h}$ after injection, i.e., the uptake was $25 \%$ higher than that of $\left.{ }^{1111} \mathrm{In}\right]$ DOTA-NAP-amide $(4.77 \pm 0.26 \% \mathrm{ID} / \mathrm{g})$, which was not expected. After $24 \mathrm{~h}$, the radioactive load was even $70 \%$ higher than with the reference

TABLE 2 | Tissue biodistribution of ${ }^{111}$ In-labeled DOTA-NAP-amide, DOTANAP-D-Asp-D-Asp, and DOTA-Phospho-MSH ${ }_{2-9}$ at 4, 24, and $48 \mathrm{~h}$ after injection into tumor-bearing mice.

\begin{tabular}{|c|c|c|c|c|}
\hline \multirow[t]{2}{*}{ Organ } & \multirow[t]{2}{*}{ Time (h) } & \multicolumn{3}{|c|}{ Uptake $\left(\%\right.$ ID/g of tissue \pm SEM) ${ }^{a}$} \\
\hline & & $\begin{array}{l}\text { DOTA-NAP- } \\
\text { amide }\end{array}$ & $\begin{array}{l}\text { DOTA-NAP- } \\
\text { D-Asp-D-Asp }\end{array}$ & $\begin{array}{c}\text { DOTA-Phospho- } \\
\text { MSH }_{2-9}\end{array}$ \\
\hline Blood & $\begin{array}{r}4 \\
24 \\
48\end{array}$ & $\begin{array}{l}0.09 \pm 0.02 \\
0.02 \pm 0.00 \\
0.00 \pm 0.00\end{array}$ & $\begin{array}{l}0.01 \pm 0.00 \\
0.01 \pm 0.00 \\
0.01 \pm 0.00\end{array}$ & $\begin{array}{l}0.02 \pm 0.00 \\
0.01 \pm 0.00 \\
0.00 \pm 0.00\end{array}$ \\
\hline Tumor & $\begin{array}{r}4 \\
24 \\
48\end{array}$ & $\begin{array}{l}7.77 \pm 0.35 \\
2.32 \pm 0.15 \\
1.41 \pm 0.12\end{array}$ & $\begin{array}{l}1.93 \pm 0.11 \\
0.63 \pm 0.03 \\
0.23 \pm 0.02\end{array}$ & $\begin{array}{l}7.33 \pm 0.47 \\
2.92 \pm 0.12 \\
1.21 \pm 0.18\end{array}$ \\
\hline Stomach & $\begin{array}{r}4 \\
24 \\
48\end{array}$ & $\begin{array}{l}0.09 \pm 0.01 \\
0.12 \pm 0.02 \\
0.11 \pm 0.05\end{array}$ & $\begin{array}{l}0.11 \pm 0.00 \\
0.03 \pm 0.00 \\
0.02 \pm 0.00\end{array}$ & $\begin{array}{l}0.17 \pm 0.08 \\
0.16 \pm 0.02 \\
0.07 \pm 0.00\end{array}$ \\
\hline Kidney & $\begin{array}{r}4 \\
24 \\
48\end{array}$ & $\begin{array}{l}4.77 \pm 0.26 \\
2.41 \pm 0.20 \\
1.55 \pm 0.07\end{array}$ & $\begin{array}{l}5.95 \pm 0.85 \\
4.09 \pm 0.16 \\
2.02 \pm 0.08\end{array}$ & $\begin{array}{l}2.68 \pm 0.18 \\
1.88 \pm 0.11 \\
1.04 \pm 0.07\end{array}$ \\
\hline Liver & $\begin{array}{r}4 \\
24 \\
48\end{array}$ & $\begin{array}{l}0.34 \pm 0.05 \\
0.31 \pm 0.02 \\
0.27 \pm 0.07\end{array}$ & $\begin{array}{l}0.10 \pm 0.00 \\
0.09 \pm 0.00 \\
0.07 \pm 0.00\end{array}$ & $\begin{array}{l}0.20 \pm 0.01 \\
0.16 \pm 0.02 \\
0.12 \pm 0.01\end{array}$ \\
\hline Spleen & $\begin{array}{r}4 \\
24 \\
48\end{array}$ & $\begin{array}{l}0.14 \pm 0.01 \\
0.11 \pm 0.01 \\
0.10 \pm 0.01\end{array}$ & $\begin{array}{l}0.07 \pm 0.00 \\
0.07 \pm 0.00 \\
0.07 \pm 0.00\end{array}$ & $\begin{array}{l}0.11 \pm 0.01 \\
0.10 \pm 0.01 \\
0.09 \pm 0.01\end{array}$ \\
\hline Lung & $\begin{array}{r}4 \\
24 \\
48\end{array}$ & $\begin{array}{l}0.08 \pm 0.01 \\
0.05 \pm 0.01 \\
0.03 \pm 0.00\end{array}$ & $\begin{array}{l}0.06 \pm 0.00 \\
0.04 \pm 0.00 \\
0.03 \pm 0.00\end{array}$ & $\begin{array}{l}0.07 \pm 0.02 \\
0.04 \pm 0.00 \\
0.03 \pm 0.00\end{array}$ \\
\hline $\begin{array}{l}\text { Small } \\
\text { intestines }\end{array}$ & $\begin{array}{r}4 \\
24 \\
48\end{array}$ & $\begin{array}{l}0.07 \pm 0.01 \\
0.08 \pm 0.01 \\
0.05 \pm 0.01\end{array}$ & $\begin{array}{l}0.05 \pm 0.01 \\
0.04 \pm 0.01 \\
0.03 \pm 0.00\end{array}$ & $\begin{array}{l}0.11 \pm 0.03 \\
0.06 \pm 0.00 \\
0.06 \pm 0.00\end{array}$ \\
\hline Pancreas & $\begin{array}{r}4 \\
24 \\
48\end{array}$ & $\begin{array}{l}0.04 \pm 0.00 \\
0.03 \pm 0.00 \\
0.02 \pm 0.00\end{array}$ & $\begin{array}{l}0.03 \pm 0.00 \\
0.02 \pm 0.00 \\
0.03 \pm 0.00\end{array}$ & $\begin{array}{l}0.05 \pm 0.01 \\
0.03 \pm 0.00 \\
0.03 \pm 0.00\end{array}$ \\
\hline Heart & $\begin{array}{r}4 \\
24 \\
48\end{array}$ & $\begin{array}{l}0.05 \pm 0.01 \\
0.03 \pm 0.00 \\
0.01 \pm 0.00\end{array}$ & $\begin{array}{l}0.03 \pm 0.00 \\
0.03 \pm 0.00 \\
0.03 \pm 0.00\end{array}$ & $\begin{array}{l}0.04 \pm 0.00 \\
0.03 \pm 0.00 \\
0.03 \pm 0.00\end{array}$ \\
\hline Bone & $\begin{array}{r}4 \\
24 \\
48\end{array}$ & $\begin{array}{l}0.11 \pm 0.02 \\
0.14 \pm 0.02 \\
0.05 \pm 0.01\end{array}$ & $\begin{array}{l}0.07 \pm 0.01 \\
0.06 \pm 0.01 \\
0.07 \pm 0.01\end{array}$ & $\begin{array}{l}0.08 \pm 0.01 \\
0.11 \pm 0.02 \\
0.06 \pm 0.01\end{array}$ \\
\hline Muscle & $\begin{array}{r}4 \\
24 \\
48\end{array}$ & $\begin{array}{l}0.05 \pm 0.01 \\
0.02 \pm 0.00 \\
0.01 \pm 0.00\end{array}$ & $\begin{array}{l}0.02 \pm 0.00 \\
0.02 \pm 0.00 \\
0.03 \pm 0.00\end{array}$ & $\begin{array}{l}0.02 \pm 0.00 \\
0.02 \pm 0.00 \\
0.02 \pm 0.00\end{array}$ \\
\hline Skin & $\begin{array}{r}4 \\
24 \\
48\end{array}$ & $\begin{array}{l}- \\
- \\
-\end{array}$ & $\begin{array}{l}0.06 \pm 0.01 \\
0.06 \pm 0.00 \\
0.04 \pm 0.00\end{array}$ & $\begin{array}{l}0.12 \pm 0.03 \\
0.07 \pm 0.02 \\
0.08 \pm 0.02\end{array}$ \\
\hline
\end{tabular}

The values are the means of three experiments each of which consisted of $n=5$ animals per compound. 


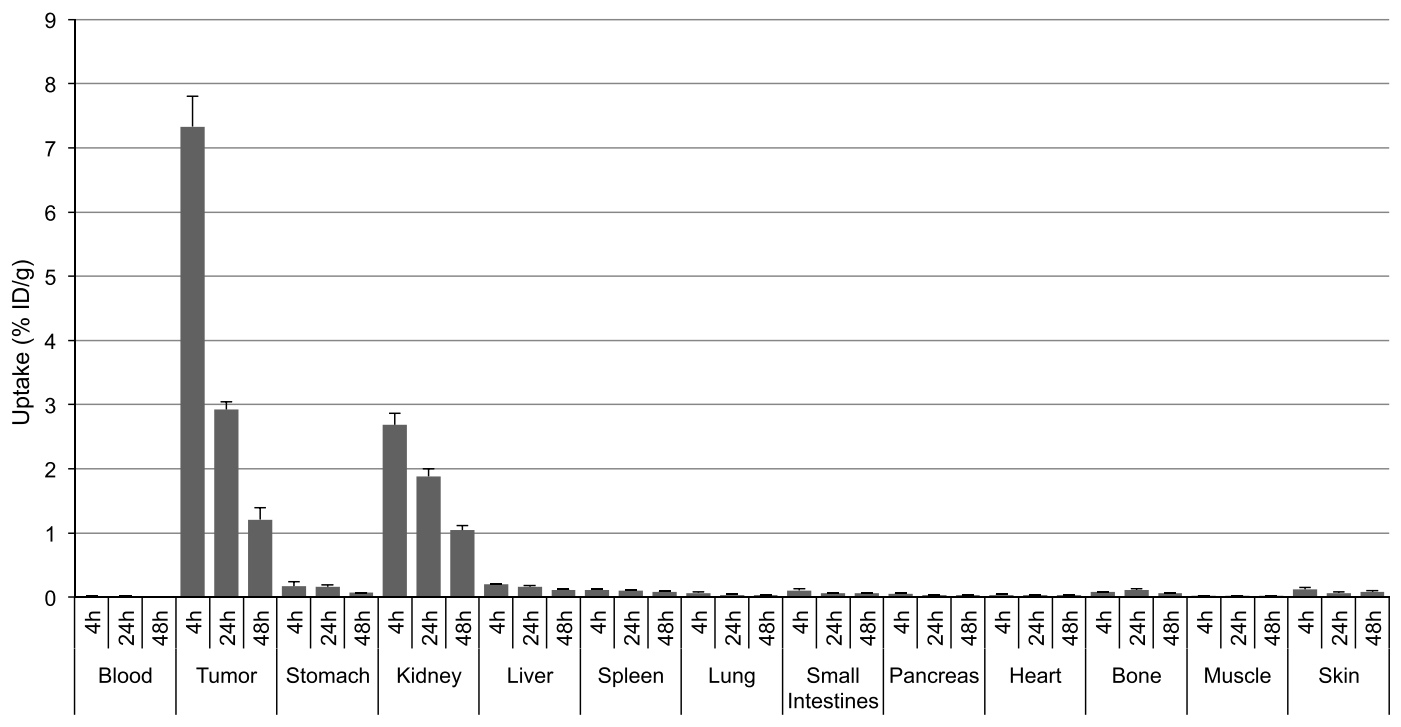

FIGURE 4 | Tissue distribution of [111In]DOTA-Phospho- MSH $_{2-9}$ in B16-F1 melanoma tumor-bearing mice at 4, 24, and 48 h postinjection. Results are expressed as percent of injected dose per g of tissue (\%ID/g; means \pm SEM; $n=3$ experiments).

peptide. On the other hand, owing to the lower receptor affinity of $\left[{ }^{111} \mathrm{In}\right]$ DOTA-NAP-D-Asp-D-Asp, it was anticipated that tumor uptake $(1.93 \pm 0.11 \% \mathrm{ID} / \mathrm{g}$ after $4 \mathrm{~h})$ was lower than that of $\left[{ }^{111} \mathrm{In}\right]$ DOTA-NAP-amide $(7.77 \pm 0.35 \% \mathrm{ID} / \mathrm{g})$. Other organs did not substantially accumulate the radiopeptide.

[111 In]DOTA-Phospho- $\mathrm{MSH}_{2-9}$ displayed more promising data: after $4 \mathrm{~h}$, tumor uptake was $7.33 \pm 0.47 \% \mathrm{ID} / \mathrm{g}$, i.e., almost identical with that of $\left.{ }^{111} \mathrm{In}\right]$ DOTA-NAP-amide, and kidney uptake was $2.68 \pm 0.18 \% \mathrm{ID} / \mathrm{g}$, which corresponds to $56 \%$ of that of the reference peptide (Table 2). Non-specific uptake by other organs was very low and did not exceed the values found with $\left[{ }^{111}\right.$ In]DOTA-NAP-amide (Figure 4), thus excluding an altered excretion pathway. Coinjection of $50 \mu \mathrm{g}$ of $\alpha$-MSH together with the radiopeptide significantly blocked melanoma uptake and confirmed MC1R-mediated internalization (data not shown). The retention of radioactivity by the tumor was decreased to $40 \%$ at $24 \mathrm{~h}$ postinjection and to $15 \%$ at $48 \mathrm{~h}$ postinjection. These data are similar to those found with other MSH radiopeptides. On the other hand, clearance from the kidney appeared to be slightly slower. The tumor-to-kidney ratios calculated for 4, 24, and $48 \mathrm{~h}$ were $2.75,1.55$, and 1.16 , respectively (Table 3 ). This results in an AUC (4-48 h) of 1.81 compared with 1.17 for [ $\left.{ }^{111} \mathrm{In}\right]$ DOTA-NAP-amide.

\section{Uptake by the Kidneys and Liver in Relation to the Overall Net Charge of MSH Analogs}

Kidney and liver uptake of $\left[{ }^{111} \mathrm{In}\right]$ DOTA-NAP-D-Asp-D-Asp,

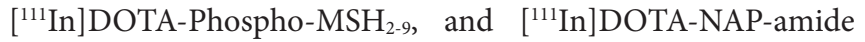
(reference peptide) was compared with that of five previously published peptides (14) that altogether cover an overall net charge ranging between +2 and -2 (Table 4 ). As shown in Figure 5, kidney uptake is lowest for net charge -1 ; it is considerably
TABLE 3 | Tumor-to-kidney ratios for tissue uptake of [111In]DOTA-NAPamide, [111 In]DOTA-NAP-D-Asp-D-Asp, and [111In]DOTA-Phospho- $\mathrm{MSH}_{2-9}$ after 4,24 , and $48 \mathrm{~h}$ postinjection.

\begin{tabular}{|c|c|c|c|}
\hline \multirow[t]{2}{*}{ Peptide } & \multicolumn{3}{|c|}{ Tumor-to-kidney ratios ${ }^{a}$} \\
\hline & $4 \mathrm{~h}$ & $24 \mathrm{~h}$ & $48 \mathrm{~h}$ \\
\hline [1111]n]DOTA-NAP-amide & 1.63 & 0.96 & 0.91 \\
\hline$\left[{ }^{111}\right.$ In]DOTA-NAP-D-Asp-D-Asp & 0.32 & 0.15 & 0.11 \\
\hline$\left[{ }^{111} 1\right.$ In]DOTA-Phospho-MSH ${ }_{2 \cdot 9}$ & 2.74 & 1.55 & 1.16 \\
\hline
\end{tabular}

aRatios are presented as quotient between the means of tumor uptake divided by means of kidney uptake (Table 2).

increased for -2 and +2 and moderately for +1 or 0 . Of the two peptides with a net charge of -1 , [ $\left.{ }^{111} \mathrm{In}\right]$ DOTA-Phospho- $\mathrm{MSH}_{2-9}$ showed a slightly lower kidney uptake than [ ${ }^{111}$ In-DOTA$\mathrm{Nle}^{4}, \mathrm{Asp}^{5}, \mathrm{D}-\mathrm{Phe}^{7}, \mathrm{Lys}^{11}$ (Suc)]- $\alpha-\mathrm{MSH}_{4-11}$-carboxylate, indicating that incorporating the negative charges in the $N$-terminal region is more advantageous than in the $C$-terminal region. In addition, the AUC (4-48 h) for [ $\left.{ }^{111} \mathrm{In}\right] \mathrm{DOTA}-\mathrm{Phospho-} \mathrm{MSH}_{2-9}$ was 1.81 , i.e., the tumor-to-kidney ratio was threefold higher than that of ${ }^{111}{ }^{1 n}$-DOTA-Nle $\left.{ }^{4}, \mathrm{Asp}^{5}, \mathrm{D}-\mathrm{Phe}^{7}, \mathrm{Lys}^{11}(\mathrm{Suc})\right]-\alpha-\mathrm{MSH}_{4}$ ${ }_{11}$-carboxylate exhibiting an AUC (4-48 h) of 0.62 (14). With respect to the liver, non-specific uptake does not follow the same pattern as outlined for the kidneys (Figure 6). Other factors such as differences in lipophilicity may play a more important role. It should be stressed, however, that liver uptake is about 20 -fold lower than that reported for the kidneys and therefore of minor importance for these peptides.

\section{DISCUSSION}

The net charge of radiolabeled peptides appears to be a crucial factor with respect to excretion via the urinary tract. The 


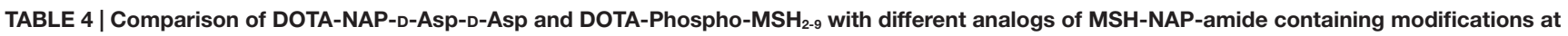
the $\mathbf{C}$-terminal or $\mathbf{N}$-terminal end or in the $\mathbf{N}^{e}$-lysine side chain that yield different overall net charges.

\begin{tabular}{|c|c|c|c|c|c|c|}
\hline \multicolumn{2}{|c|}{ Peptide } & \multirow{2}{*}{$\begin{array}{l}\boldsymbol{N} \text {-terminal } \\
\mathrm{AC}\end{array}$} & \multirow{2}{*}{$\begin{array}{l}\text { C-terminal } \\
\text { D-Asp-D-Asp }\end{array}$} & \multirow{2}{*}{$\begin{array}{l}\mathbf{N}^{\varepsilon} \text {-Lys } \\
\text { DOTA }\end{array}$} & \multirow{2}{*}{$\begin{array}{c}\text { Net charge } \\
-2\end{array}$} & \multirow[t]{2}{*}{ Reference } \\
\hline A & 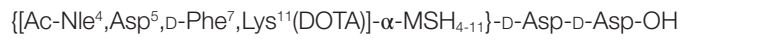 & & & & & \\
\hline $\mathrm{B}$ & $\left[\mathrm{DOTA}-\mathrm{Gly}{ }^{2}, \mathrm{Tyr}(\mathrm{P})^{3}, \mathrm{Nle}^{4}, \mathrm{Asp}^{5}, \mathrm{D}-\mathrm{Phe}^{7}\right]-\alpha-\mathrm{MSH}_{2-9}$ [DOTA-Phospho-MSH $\left.{ }_{2-9}\right]$ & DOTA & Trp-amide & - & -1 & \\
\hline C & {$\left[\mathrm{DOTA}-\mathrm{Nle}^{4}, \mathrm{Asp}^{5}, \mathrm{D}-\mathrm{Phe}^{7}, \mathrm{Lys}^{11}(\mathrm{Suc})\right]-\alpha-\mathrm{MSH}_{4-11}$-carboxylate } & DOTA & $\mathrm{OH}$ & Suc & -1 & $(14)$ \\
\hline $\mathrm{D}$ & {$\left[\right.$ DOTA-Nle ${ }^{4}$, Asp $^{5}, \mathrm{D}-\mathrm{Phe}^{7}$, Lys $\left.^{11}(\mathrm{Suc})\right]-\alpha-\mathrm{MSH}_{4-11}$} & DOTA & Amide & Suc & 0 & $(14)$ \\
\hline$E$ & {$\left[\mathrm{Ac}-\mathrm{Nle}^{4}, \mathrm{Asp}^{5}, \mathrm{D}-\mathrm{Phe}^{7}, \mathrm{Lys}^{11}(\mathrm{DOTA})\right]-\alpha-\mathrm{MSH}_{4-11}-$ carboxylate } & Ac & $\mathrm{OH}$ & DOTA & 0 & (14) \\
\hline $\mathrm{F}$ & {$\left[\right.$ Ac-Nle $\left.{ }^{4}, \mathrm{Asp}^{5}, \mathrm{D}-\mathrm{Phe}^{7}, \mathrm{Lys}^{11}(\mathrm{DOTA})\right]-\alpha-\mathrm{MSH}_{4-11}$ [DOTA-NAP-amide] } & Ac & Amide & DOTA & +1 & (13) \\
\hline G & {$\left[\right.$ DOTA-Nle $\left.{ }^{4}, \mathrm{Asp}^{5}, \mathrm{D}-\mathrm{Phe}^{7}, \mathrm{Lys}^{11}(\mathrm{Ac})\right]-\alpha-\mathrm{MSH}_{4-11}$} & DOTA & Amide & Ac & +1 & $(14)$ \\
\hline $\mathrm{H}$ & {$\left[\mathrm{DOTA}-\mathrm{Nle}^{4}, \mathrm{Asp}^{5}, \mathrm{D}-\mathrm{Phe}^{7}\right]-\alpha-\mathrm{MSH}_{4-11}$} & DOTA & Amide & $\mathrm{H}$ & +2 & $(14)$ \\
\hline
\end{tabular}

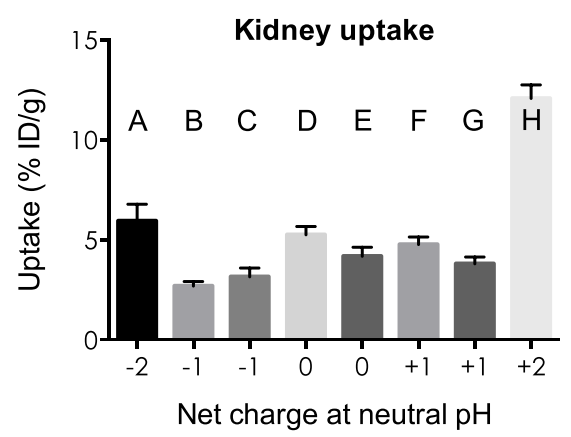

FIGURE 5 | Uptake by the kidneys of eight different ${ }^{111}$ In-labeled DOTA-MSH peptides with net charges ranging from -2 to +2 . For structures of peptides $\mathrm{A}-\mathrm{H}$, see Table 4. Results are expressed as percent of injected dose per gram of tissue (\%ID/g; means $\pm \mathrm{SEM} ; n=3)$.

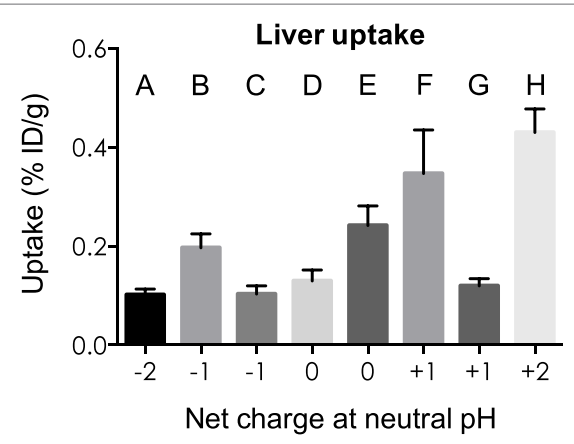

FIGURE 6 | Uptake by the liver of eight different ${ }^{111}$ In-labeled DOTA-MSH peptides with net charges ranging from $-\mathbf{2}$ to $+\mathbf{2}$. For structures of peptides A-H, see Table 4. Results are expressed as percent of injected dose per gram of tissue $(\% \mathrm{ID} / \mathrm{g}$; means $\pm \mathrm{SEM} ; n=3)$.

negatively charged surface of tubular cells of the kidneys involves repulsing electrostatic effects on negatively charged molecules passing in the luminal part of the proximal tubules, thus reducing their (re-)uptake $(30,41)$. As already mentioned, this effect can be further enhanced by the presence of positively charged amino acids such as Lys and Arg (42). An earlier study in our laboratory comparing differently charged DOTA-NAP-amide type of peptides demonstrated that ${ }^{[11}$ In-DOTA-Nle ${ }^{4}, \mathrm{Asp}^{5}$, $\left.\mathrm{D}-\mathrm{Phe}^{7}, \mathrm{Lys}^{11}(\mathrm{Suc})\right]-\alpha-\mathrm{MSH}_{4-11}$-carboxylate with a net charge of
-1 exhibited the lowest kidney uptake but was nevertheless not an alternative to [ ${ }^{111} \mathrm{In}$ ]DOTA-NAP-amide because of the lower MC1R affinity and reduced uptake by melanoma tumors (14). With the new peptide DOTA-NAP-D-Asp-D-Asp (net charge -2 ), the question of a potentially positive effect of an additional negative charge at the $C$-terminus was addressed. In vitro, this peptide showed rapid internalization by cultured B16-F1 melanoma cells despite an $\sim 10$-fold reduced MC1R affinity compared to DOTA-NAP-amide. In vivo, uptake by melanoma tumors was $\sim 4$-fold lower, but uptake/retention by the kidneys was markedly increased. These findings would contradict the expectation of an even higher electrostatic repulsion on the surface of tubular cells. It is possible that once internalized, the fragmentation of the C-terminal region of DOTA-NAP-D-Asp-D-Asp is retarded by the $\mathrm{D}$-Asp residues and excretion of Lys([111 In]DOTA), a metabolite of internalized [ $\left.{ }^{111} \mathrm{In}\right]$ DOTA-NAP-amide occurring $4 \mathrm{~h}$ after injection (Froidevaux and Eberle, unpublished), is slower than for the reference compound. In summary, addition of a total of three negative charges to the $C$-terminus of DOTANAP-amide, yielding a net charge of -2 of the molecule, impairs its pharmacokinetic properties.

To find an alternative to [DOTA-Nle $\left.{ }^{4}, \mathrm{Asp}^{5}, \mathrm{D}-\mathrm{Phe}^{7}, \mathrm{Lys}^{11}(\mathrm{Suc})\right]$ $\alpha-\mathrm{MSH}_{4-11}$-carboxylate with a net charge of -1 but higher tumor uptake, we aimed at incorporating the negative charges in the $N$-terminal region of the molecule. To this end, DOTA-Phospho$\mathrm{MSH}_{2-9}$ was prepared, which contains a phosphate group in the phenolic ring of $\mathrm{Tyr}^{2}$ of the $\mathrm{MSH}_{2-9}$ peptide fragment. This peptide exhibited almost the same in vitro characteristics as the reference compound DOTA-NAP-amide. In particular, [ $\left.{ }^{111} \mathrm{In}\right]$ DOTA-Phospho- $\mathrm{MSH}_{2-9}$ was very rapidly internalized by cultured B16-F1 cells and reached the plateau after $3.5 \mathrm{~h}$. In vivo, tumor uptake was about as high as for the reference compound but kidney uptake was markedly lower leading to the most favorable tumor-to-kidney ratio of a linear DOTA-MSH radiopeptide reported to date. All other compounds with net charges from +2 to 0 displayed less favorable tumor-to-kidney ratios. In conclusion, linear DOTA-MSH peptides preferably have an overall net charge of -1 , and the additional negative charges are incorporated in the $N$-terminal region.

While the experimental work with the two new ${ }^{111}$ In-labeled MSH radiopeptides described here was already completed, the group of Miao and collaborators published several new lactambridged cyclized MSH analogs containing DOTA and NOTA chelators (for ${ }^{111} \mathrm{In},{ }^{67 / 68} \mathrm{Ga},{ }^{90} \mathrm{Y}$ ) or $\mathrm{MAG}_{3}$ and HYNIC chelators 
(for ${ }^{99 \mathrm{~m} T c},{ }^{188} \mathrm{Re}$ ) for which they found considerably superior biodistribution data (43-46) compared to those with previously published cyclic MSH analogs. These novel cyclic MSH analogs may even be superior to DOTA-Phospho- $\mathrm{MSH}_{2-9}$, but this would have to be examined in a comparative study under the same experimental conditions with DOTA-Phospho- $\mathrm{MSH}_{2-9}$ to define a potentially even more attractive novel lead compound.

\section{ETHICS STATEMENT}

All animal experiments were performed in compliance with Swiss animal welfare regulations and were ethically approved by the Ethics Committee for Animal Experimentation of the University Hospital Basel, followed by review and approval by the Cantonal

\section{REFERENCES}

1. Dennis LK. Analysis of the melanoma epidemic, both apparent and real: data from the 1973 through 1994 surveillance, epidemiology, and end results program registry. Arch Dermatol (1999) 135:275-80. doi:10.1001/ archderm.135.3.275

2. Wick MR. Cutaneous melanoma: a current overview. Semin Diagn Pathol (2016) 33:225-41. doi:10.1053/j.semdp.2016.04.007

3. Ghanem GE, Comunale G, Libert A, Vercammen-Grandjean A, Lejeune FJ. Evidence for $\alpha$-melanocyte-stimulating hormone ( $\alpha$-MSH) receptors on human malignant melanoma cells. Int J Cancer (1988) 41:248-55. doi:10.1002/ ijc. 2910410216

4. Siegrist W, Solca F, Stutz S, Giuffre L, Carrel S, Girard J, et al. Characterization of receptors for $\alpha$-melanocyte-stimulating hormone on human melanoma cells. Cancer Res (1989) 49:6352-8.

5. Loir B, Pérez Sánchez C, Ghanem G, Lozano JA, García-Borrón JC, JiménezCervantes G. Expression of the MC1 receptor gene in normal and malignant human melanocytes. A semiquantitative RT-PCR study. Cell Mol Biol (1999) 45:1083-92.

6. Eberle AN, Bapst JP, Calame M, Tanner H, Froidevaux S. MSH radiopeptides for melanoma targeting. Adv Exp Med Biol (2010) 681:133-42. doi:10.1007/978-1-4419-6354-3_11

7. Rozenkrants AA, Lunin VG, Sergienko OV, Giliazova DG, Voronina OL, Ians DE, et al. Targeted intracellular site-specific drug delivery: photosensitizer targeting to melanoma cell nuclei. Genetika (2003) 39:259-68.

8. Sawyer TK, Sanfilippo PJ, Hruby VJ, Engel MH, Heward CB, Burnett JB, et al. 4-Norleucine, 7-D-phenylalanine- $\alpha$-melanocyte-stimulating hormone: a highly potent $\alpha$-melanotropin with ultralong biological activity. Proc Natl Acad Sci U S A (1980) 77:5754-8. doi:10.1073/pnas.77.10.5754

9. Al-Obeidi F, Castrucci AM, Hadley ME, Hruby VJ. Potent and prolonged acting cyclic lactam analogues of $\alpha$-melanotropin: design based on molecular dynamics. J Med Chem (1989) 32:2555-61. doi:10.1021/jm00132a010

10. Cai M, Hruby VJ. Design of cyclized selective melanotropins. Biopolymers (2016) 106:873-86. doi:10.1002/bip.22976

11. Bagutti C, Stolz B, Albert R, Bruns C, Pless J, Eberle AN. [ ${ }^{111}$ In]-DTPAlabeled analogues of $\alpha$-melanocyte-stimulating hormone for melanoma targeting: receptor binding in vitro and in vivo. Int J Cancer (1994) 58:749-55. doi:10.1002/ijc.2910580521

12. Froidevaux S, Calame-Christe M, Tanner H, Sumanovski L, Eberle AN. A novel DOTA- $\alpha$-melanocyte-stimulating hormone analog for metastatic melanoma diagnosis. J Nucl Med (2002) 43:1699-706.

13. FroidevauxS,Calame-ChristeM,SchuhmacherJ,TannerH,SaffrichR,HenzeM, et al. A gallium-labeled DOTA- $\alpha$-melanocyte-stimulating hormone analog for PET imaging of melanoma metastases. J Nucl Med (2004) 45:116-23.

14. Froidevaux S, Calame-Christe M, Tanner H, Eberle AN. Melanoma targeting with DOTA- $\alpha$-melanocyte-stimulating hormone analogs: structural parameters affecting tumor uptake and kidney uptake. J Nucl Med (2005) 46:887-95.

15. Bapst JP, Calame M, Tanner H, Eberle AN. Glycosylated DOTA- $\alpha$-melanocytestimulating hormone analogues for melanoma targeting: influence of the site
Commission for Animal Experimentation of Basel. No human data were used in this study.

\section{AUTHOR CONTRIBUTIONS}

$\mathrm{J}-\mathrm{PB}$ and $\mathrm{AE}$ contributed substantially to the conception and design of the work, the acquisition, analysis and interpretation of data, and the drafting of the work.

\section{ACKNOWLEDGMENTS}

The authors thank the Swiss National Science Foundation for financial support (project no. 3100A0-102169) and Dr. Martine Christe and Mrs. Heidi Tanner for expert technical assistance. of glycosylation on in vivo biodistribution. Bioconjug Chem (2009) 20:984-93. doi:10.1021/bc900007u

16. De Visser M, Verwijnen SM, de Jong M. Update: improvement strategies for peptide receptor scintigraphy and radionuclide therapy. Cancer Biother Radiopharm (2008) 23:137-57. doi:10.1089/cbr.2007.0435

17. Eberle AN, Mild G. Receptor-mediated tumor targeting with radiopeptides. Part 1. General principles and methods. J Recept Signal Transduct Res (2009) 29:1-37. doi:10.1080/10799890902732823

18. Guo H, Yang J, Gallazzi F, Prossnitz ER, Sklar LA, Miao Y. Effect of DOTA position on melanoma targeting and pharmacokinetic properties of ${ }^{111} \mathrm{In}$-labeled lactam bridge-cyclized $\alpha$-melanocyte stimulating hormone peptide. Bioconjug Chem (2009) 20:2162-8. doi:10.1021/bc9003475

19. Yang J, Guo H, Padilla RS, Berwick M, Miao Y. Replacement of the Lys linker with an Arg linker resulting in improved melanoma uptake and reduced renal uptake of ${ }^{99 m} \mathrm{mc}$-labeled Arg-Gly-Asp-conjugated $\alpha$-melanocyte stimulating hormone hybrid peptide. Bioorg Med Chem (2010) 18:6695-700. doi:10.1016/ j.bmc.2010.07.061

20. Bapst JP, Froidevaux S, Calame M, Tanner H, Eberle AN. Dimeric DOTA$\alpha$-melanocyte-stimulating hormone analogs: synthesis and in vivo characteristics of radiopeptides with high in vitro activity. J Recept Signal Transduct Res (2007) 27:383-409. doi:10.1080/10799890701723528

21. Giblin MF, Wang N, Hoffman TJ, Jurisson SS, Quinn TP. Design and characterization of $\alpha$-melanotropin peptide analogs cyclized through rhenium and technetium metal coordination. Proc Natl Acad Sci U S A (1998) 95:12814-8. doi:10.1073/pnas.95.22.12814

22. Chen J, Cheng Z, Owen NK, Hoffman TJ, Miao Y, Jurisson SS, et al. Evaluation of an ${ }^{111}$ In-DOTA-rhenium cyclized $\alpha$-MSH analog: a novel cyclic-peptide analog with improved tumor-targeting properties. J Nucl Med (2001) 42:1847-55.

23. Cheng Z, Chen J, Miao Y, Owen NK, Quinn TP, Jurisson SS. Modification of the structure of a metallopeptide: synthesis and biological evaluation of ${ }^{111}$ In-labeled DOTA-conjugated rhenium-cyclized $\alpha$-MSH analogues. J Med Chem (2002) 45:3048-56. doi:10.1021/jm010408m

24. Miao Y, Whitener D, Feng W, Owen NK, Chen J, Quinn TP. Evaluation of the human melanoma targeting properties of radiolabeled $\alpha$-melanocyte stimulating hormone peptide analogues. Bioconjug Chem (2003) 14:1177-84. doi:10.1021/bc034069i

25. Miao Y, Hoffman TJ, Quinn TP. Tumor-targeting properties of ${ }^{90} \mathrm{Y}-$ and ${ }^{177} \mathrm{Lu}$-labeled $\alpha$-melanocyte-stimulating hormone peptide analogues in a murine melanoma model. Nucl Med Biol (2005) 32:485-93. doi:10.1016/ j.nucmedbio.2005.03.007

26. Miao Y, Fisher DR, Quinn TP. Reducing renal uptake of ${ }^{90} \mathrm{Y}$ - and ${ }^{177} \mathrm{Lu}$-labeled $\alpha$-melanocyte-stimulating hormone peptide analogues. Nucl Med Biol (2006) 33:723-33. doi:10.1016/j.nucmedbio.2006.06.005

27. Miao Y, Benwell K, Quinn TP. ${ }^{99 \mathrm{~m} T c-}$ and ${ }^{111} \mathrm{In}$-labeld $\alpha$-melanocytestimulating hormone peptides as imaging probes for primary and pulmonary metastatic melanoma detection. J Nucl Med (2007) 48:73-80.

28. Miao Y, Gallazzi F, Guo H, Quinn TP. ${ }^{11}$ In-labeled lactam bridge-cyclized $\alpha$-melanocyte stimulating hormone peptide analogues for 
melanoma imaging. Bioconjug Chem (2008) 19:539-47. doi:10.1021/ bc700317w

29. Gao F, Sihver W, Jurischka C, Bergmann R, Haase-Kohn C, Mosch B, et al. Radiopharmacological characterization of ${ }^{64} \mathrm{Cu}$-labeled $\alpha$-MSH analogs for potential use in imaging of malignant melanoma. Amino Acids (2016) 48:833-47. doi:10.1007/s00726-015-2131-x

30. Behr TM, Goldenberg DM, Becker W. Reducing the renal uptake of radiolabeled antibody fragments and peptides for diagnosis and therapy: present status, future prospects and limitations. Eur J Nucl Med (1998) 25:201-12. doi:10.1007/s002590050216

31. Hammond PJ, Wade AF, Gwilliam ME, Peters AM, Myers MJ, Gilbey SG, et al. Amino acid infusion blocks renal tubular uptake of an indium-labelled somatostatin analogue. Br J Cancer (1993) 67:1437-9. doi:10.1038/bjc.1993.266

32. Bernard BF, Krenning EP, Breeman WA, Rolleman EJ, Bakker WH, Visser TJ, et al. D-lysine reduction of indium-111 octreotide and yttrium-90 octreotide renal uptake. J Nucl Med (1997) 38:1929-33.

33. Bodei L, Cremonesi M, Zoboli S, Grana C, Bartolomei M, Rocca P, et al. Receptor-mediated radionuclide therapy with ${ }^{90} \mathrm{Y}$-DOTATOC in association with amino acid infusion: a phase I study. Eur J Nucl Med Mol Imaging (2003) 30:207-16. doi:10.1007/s00259-002-1023-y

34. Miao Y, Owern NK, Whitener D, Gallazzi F, Hoffman TJ, Quinn TP. In vivo evaluation of ${ }^{188} \mathrm{Re}$-labeled $\alpha$-melanocyte stimulating hormone peptide analogs for melanoma therapy. Int J Cancer (2002) 101:480-7. doi:10.1002/ ijc. 10640

35. Christensen EI, Rennke HG, Carone FA. Renal tubular uptake of protein: effect of molecular charge. Am J Physiol (1983) 244:F436-41.

36. Lawrence GM, Brewer DB. Glomerular ultrafiltration and tubular reabsorption of bovine serum albumin and derivatives with increased negative charge in the normal female Wistar rat. Clin Sci (Lond) (1984) 66:47-54. doi:10.1042/ cs0660047

37. Kok RJ, Haas M, Moolenaar F, de Zeeuw D, Meijer DK. Drug delivery to the kidneys and the bladder with the low molecular weight protein lysozyme. Ren Fail (1998) 20:211-7. doi:10.3109/08860229809045104

38. Akizawa H, Arano Y, Mifune M, Iwado A, Saito Y, Mukai T, et al. Effect of molecular charges on renal uptake of ${ }^{111} \mathrm{In}$-DTPA-conjugated peptides. Nucl Med Biol (2001) 28:761-8. doi:10.1016/S0969-8051(01)00241-4
39. Fidler IJ. Selection of successive tumour lines for metastasis. Nat New Biol (1973) 242:148-9. doi:10.1038/newbio242148a0

40. Siegrist W, Eberle AN. In situ melanin assay for MSH using mouse B16 melanoma cells in culture. Anal Biochem (1986) 159:191-7. doi:10.1016/0003-2697 (86)90327-1

41. Deen WM, Satvat B, Jamieson JM. Theoretical model for glomerular filtration of charged solutes. Am J Physiol (1980) 238:F126-39.

42. Rolleman EJ, Valkema R, de Jong M, Kooij PP, Krenning EP. Safe and effective inhibition of renal uptake of radiolabelled octreotide by a combination of lysine and arginine. Eur J Nucl Med Mol Imaging (2003) 30:9-15. doi:10.1007/ s00259-002-0982-3

43. Guo H, Gallazzi F, Miao Y. Gallium-67-labeled lactam bridge-cyclized $\alpha$ MSH peptides with enhanced melanoma uptake and reduced renal uptake. Bioconjug Chem (2012) 23:1341-8. doi:10.1021/bc300191z

44. Guo H, Miao Y. Cu-64-labeled lactam bridge-cyclized $\alpha$-MSH peptides for PET imaging of melanoma. Mol Pharm (2012) 9:2322-30. doi:10.1021/ mp300246j

45. Guo H, Gallazzi F, Miao Y. Design and evaluation of new ${ }^{99 m}$ Tc-labeled lactam-bridge-cyclized $\alpha$-MSH peptides for melanoma imaging. Mol Pharm (2013) 10:1400-8. doi:10.1021/mp3006984

46. Guo H, Miao Y. Introduction of an 8-aminooctanoic acid linker enhances the melanoma uptake of ${ }^{99 \mathrm{~m}} \mathrm{Tc}$-labeled lactam-bridge-cyclized $\alpha$-MSH peptide. J Nucl Med (2014) 55:2057-63. doi:10.2967/jnumed.114. 145896

Conflict of Interest Statement: The authors declare that the research was conducted in the absence of any commercial or financial relationships that could be construed as a potential conflict of interest.

Copyright (c) 2017 Bapst and Eberle. This is an open-access article distributed under the terms of the Creative Commons Attribution License (CC BY). The use, distribution or reproduction in other forums is permitted, provided the original author(s) or licensor are credited and that the original publication in this journal is cited, in accordance with accepted academic practice. No use, distribution or reproduction is permitted which does not comply with these terms. 